\title{
Fish Community Structure of Sandha River: A Link Analysis towards Fisheries Management and Conservation
}

\author{
Ruma $\mathbf{M}^{1}$, Hossain MM${ }^{1}$, Rahman MB $^{2}$, Nahar A $^{3^{*}}$ and Siddik MAB ${ }^{4}$ \\ ${ }^{1}$ Department of Fisheries Management, Patuakhali Science and Technology University, Bangladesh \\ ${ }^{2}$ Department of Fisheries Technology, Patuakhali Science and Technology University, Bangladesh \\ ${ }^{3}$ Department of Marine Fisheries and Oceanography, Patuakhali Science and Technology University, Bangladesh \\ ${ }^{4}$ Department of Fisheries Biology and Genetics, Patuakhali Science and Technology University, Bangladesh
}

\begin{abstract}
Sandha River water regime is used as a nursery, feeding and breeding places by commercially important fish species due to the presence of unique environment. Therefore, the present study has been conducted to assess water quality parameters, fish species abundance, fish diversity indices, conservation issues and management policy to guard the valuable aquatic resources of Sandha River from March 2015 to February 2016. Among the water quality parameters, temperature and $\mathrm{pH}$ were found at a slight rising level which possessed insignificant negative correlation with fish species abundance $(p<0.01)$. Fish diversity indices were calculated of which the value of Shannon-Wiener Index just above 3 which indicated the river ecosystem still approving good fish community structure where lower value of richness described short food webs. Garretts Ranking Technique was applied to identify the reasons behind the decline of Sandha River fish species over the periods. The study, therefore, concluded that the river has experienced with slight climate modifications and significant anthropogenic activities especially huge fishing pressure which in a feedback reduce the fisheries stock resources with time. Community-based fisheries management (CBFM) hence would be an appropriate tool to make the water resources sustainable.
\end{abstract}

Keywords: Sandha River; Water Quality Parameters; ShannonWiener Index; Fishing Pressure; CBFM

\section{Introduction}

Fish as a foodstuff have established an essential constitute to supply cheap source of nutrition's especially protein $[1,2]$ for much of the world's population mainly low-revenue food-deficit countries [3]. Along with the globe, fisheries sector of Bangladesh has incredible utility in poverty alleviation, food security, nutrition supply, sources of income, employment generations, foreign exchange earnings and overall on the socio-economic development of Bangladesh [4,5]. The fisheries resources of the country are mainly captured based from inland open and closed water resources. As an outcome, the diversity of fish faunal communities is under stress due to intense exploitation by illegal fishing gears [6,7]. Environmental modifications (climate changes) also claimed as one of the leading issues for reducing fish species from open water bodies [8,9].

In nature, Pirojpur is a coastal riverine district with huge fishery resources situated at the southern part of Bangladesh. In the life and living status of fishers of Pirojpur district, Sandha River has an important job to endow with food security and sole source of returns support through fish business activities of many household families. Thus, the river has great influence to change life pattern and sustain of riverine population community the southern coastal region of Bangladesh primarily depend on resources from the river. But at the meantime, the worthwhile aquatic resources of Sandha River are in declining trends like others water resources of Bangladesh due to both anthropogenic activities and environmental alterations $[4,10,11]$. Very earlier study by Hanif et al. [12] identified total 26 threatened fish species from Sandha River and found environmental degradation and over-exploitation using restricted fishing gears was the important factors for threatening the ichthyofaunal community. Ship breaking activities, point and nonpoint sources of pollution, fishing during ban period, introduction of alien species from aquaculture ponds and pesticides from croplands, use of restricted fishing gears and finally excess fishing pressure throughout the year causes the alternations of river bed, change the water quality parameters and in combination make the river unsuitable for fish community. As a result, diversity of fish species from Sandha River is gradually decreasing with increasing excess fishing pressure and other possible factors. Therefore, in view of the above information's, the present study has been undertaken to assess water quality parameters, fish species abundance, fish diversity indices, conservation issues and management policy to guard the valuable aquatic resources of Sandha River of Bangladesh.

\section{Materials and Methods}

\section{Study area and duration}

The present study was conducted in Sandha River, located in Swarupkathi upazilla with geographical position lies between $22^{\circ} 44^{\prime} 50^{\prime \prime}$ to $22^{\circ} 74^{\prime} 72^{\prime \prime} \mathrm{N}$ and $90^{\circ} 06^{\prime} 13^{\prime \prime}$ to $90^{\circ} 10^{\prime} 36^{\prime \prime} \mathrm{E}$. (Figure 1). The river Sandha with a total length of about $50 \mathrm{~km}$ originating from the Meghna River near Muladi upazilla and then falls to the Bay of Bengal over through two coastal districts named Barisal and Pirojpur. The study duration was 6 months from March 2015 to February 2016.

\section{Hydrological parameters analysis}

Hydrological parameters like salinity was measured using a

*Corresponding author: Nahar A, Department of Marine Fisheries and Oceanography, Faculty of Fisheries, Patuakhali Science and Technology University, Bangladesh, Tel: 0442756317; E-mail: nahar@pstu.ac.bd

Received June 29, 2017; Accepted August 08, 2017; Published August 15, 2017 Citation: Ruma M, Hossain MM, Rahman MB, Nahar A, Siddik MAB (2017) Fish Community Structure of Sandha River: A Link Analysis towards Fisheries Management and Conservation. J Biodivers Endanger Species 5: 192. doi: 10.4172/2332-2543.1000192

Copyright: ( 2017 Ruma M, et al. This is an open-access article distributed unde the terms of the Creative Commons Attribution License, which permits unrestricted use, distribution, and reproduction in any medium, provided the original author and source are credited. 
Citation: Ruma M, Hossain MM, Rahman MB, Nahar A, Siddik MAB (2017) Fish Community Structure of Sandha River: A Link Analysis towards Fisheries Management and Conservation. J Biodivers Endanger Species 5: 192. doi: 10.4172/2332-2543.1000192

refractometer (CBF 062, Japan), $\mathrm{pH}$ using a $\mathrm{pH}$ meter (pH 211, Hanna Instruments, Italy), a temperature meter to measure temperature and a DO meter (AZ8402, China) to measure dissolved oxygen concentration. A Secchi disc ( $20 \mathrm{~cm}$ diameter) was used to measure the water transparency.

\section{Fish specimen collection and identification}

Fish specimens were collected from six selected fishing spots (St1, St2, St3, St4, St5 and St6) of Sandha River. At each sampling day, three types of fishing gears (SBN- Set Beg Net, Fixed net and cast net) were used for sampling purpose. The collected specimens were placed in ice-box with adequate ice facilities. Then, total numbers of individual species were counted in each sampling day and recorded according to months and stations. For laboratory study, $10 \%$ of the total catch was taken from each sampling station covering the representative group of fish. In the laboratory, the collected specimens were identified to species level with the help of standard taxonomic keys of [13-16].

\section{Data analysis}

Species diversity was assessed using four different indices viz., species richness, Shannon-Wiener diversity, Evenness and Dominance Indices in a spatial and temporal spectrum. Shannon-Weiner diversity index $[17,18]$ is used for better understanding of fish biodiversity and calculated by the following formula:

$$
H=-\sum\left[\left(\frac{n i}{N}\right) \times \ln \left(\frac{n i}{N}\right)\right] \mathrm{N} \text { is total individuals and ni is the number }
$$

of individuals of species $i$.
Buzas and Gibson's evenness [19] is measured by using $E=\frac{e H}{S}$ formula; where, $e$ is logarithm base, $\mathrm{H}$ is Shannon-Wiener Index and $\mathrm{S}$ is number of taxa.

Simpson's dominance index (D) $[19,20]$ is measured by the following formula: $D=\sum\left[\frac{n i(n i-1)}{N(N-1)}\right]$; where, ni is number of
individuals of species i.

Simpson's index of diversity (1-D) is determined using $1-D=1-\sum\left[\frac{n i(n i-1)}{N(N-1)}\right]$ formula; where, $\mathrm{N}$ is total individuals and ni is the number of individuals of species $i$.

Margalef richness index (d) [21,22] is used to measure species richness by using the formula: $d=\frac{S-1}{\ln N}$; where, $\mathrm{S}$ is the number of taxa
and $\mathrm{N}$ is total individuals.

SPSS statistical package (SPSS 16.0 for Windows, SPSS Inc, Chicago, IL, USA), PAST software (2.17c) [23] and BioDiversity Pro statistics software (2.0) [24] were used for analysis purpose.

An open-ended interview schedule was used among 500 randomly selected fishermen to collect data about the reasons perceived by the fisheries regarding the decline in fish. The ranks given by the respondents were then converted into percentage position with the help of following Garretts Ranking Technique [25].

$$
\text { PercentagePosition }=\frac{100 \times(R i j-0.5)}{N j}
$$

Where, Rij= Rank given to $\mathrm{i}^{\text {th }}$ constraint by $\mathrm{j}^{\text {th }}$ individual, $\mathrm{Nj}=$ Number of constraints ranked by $\mathrm{j}^{\text {th }}$ individual.

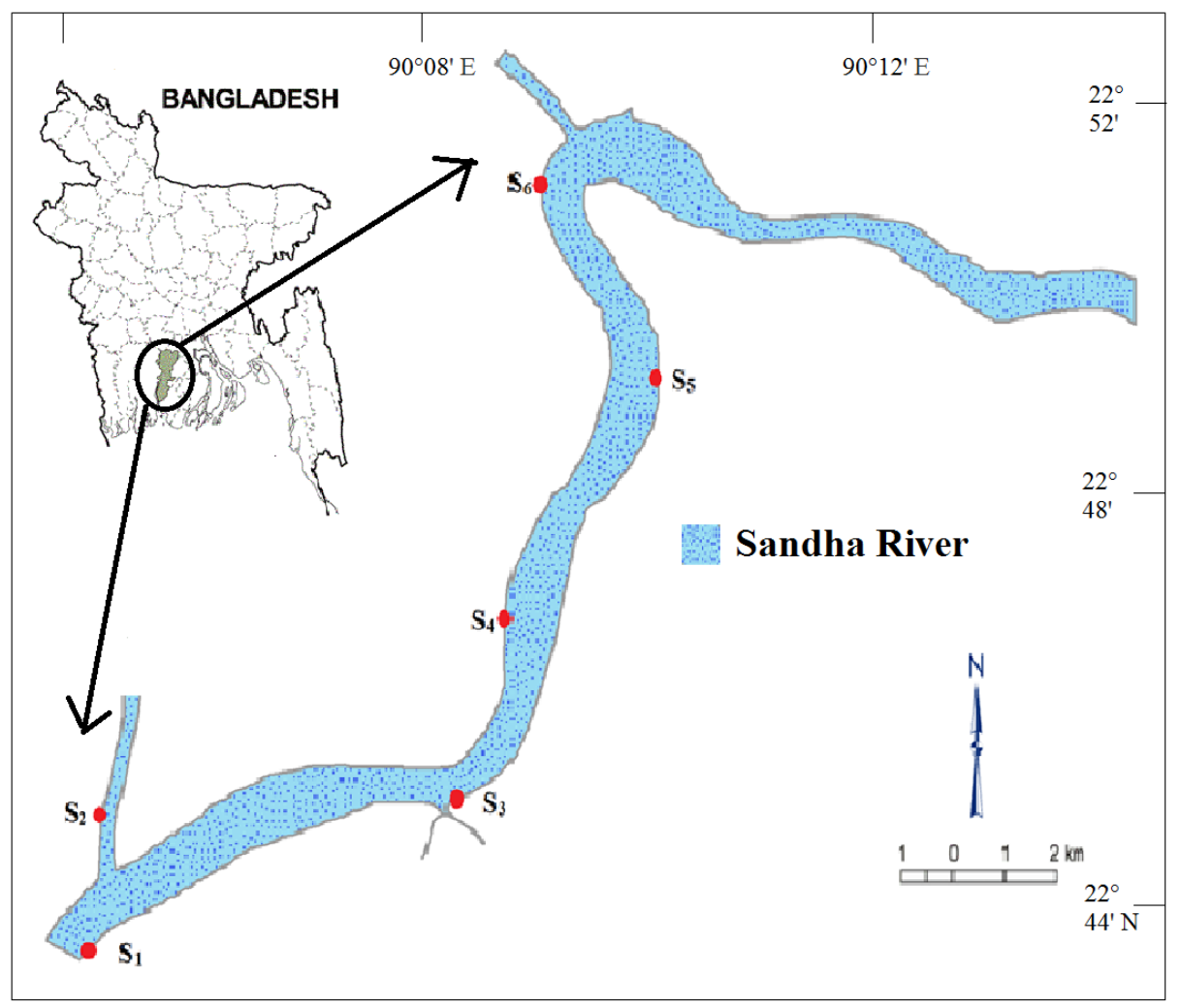

Figure 1: Location of Sandha River with six sampling zones in Bangladesh 
Citation: Ruma M, Hossain MM, Rahman MB, Nahar A, Siddik MAB (2017) Fish Community Structure of Sandha River: A Link Analysis towards Fisheries Management and Conservation. J Biodivers Endanger Species 5: 192. doi: 10.4172/2332-2543.1000192

Page 3 of 8

\section{Results}

\section{Hydrological parameters}

Higher water temperature $\left(28.35^{\circ} \mathrm{C}\right)$ was found during July 2015 which followed by May 2015 and lower temperature $\left(21.95^{\circ} \mathrm{C}\right)$ during February 2016 (Table 1). A non-significant difference in Temperature was observed during the months of March and September $(\mathrm{p}<0.05)$ while a significant difference was found for other four months (July, May, November, and February) ( $\mathrm{p}>0.05)$. After temperature, another important water quality parameter was $\mathrm{pH}$ which found maximum (7.65) during July 2015 where minimum (6.50) for February 2016. A non-significant difference in water $\mathrm{pH}$ was found for March, May, and September and for November and February $(\mathrm{p}<0.05)$. Dissolved oxygen (DO) was observed maximum $(6.95 \mathrm{mg} / \mathrm{l})$ in February 2016 and minimum $(5.23 \mathrm{mg} / \mathrm{l})$ in March $2015(\mathrm{p}<0.05)$. Transparency was found highest $(37.17 \mathrm{~cm})$ during February 2016 and lowest $(26.07 \mathrm{~cm})$ in the month of March 2015 ( $\mathrm{p}<0.05)$. But at stations level, a nonsignificant difference among the water quality parameters was shown during the whole study period $(\mathrm{p}<0.05)$ (Table 1$)$.

The temperature had significant positive correlation with $\mathrm{pH}$ where $\mathrm{r}=0.790$ and considerable negative correlation with DO and Transparency $(\mathrm{p}<0.01)$ where $\mathrm{r}=-0.690$ and -0.803 , respectively (Table 2). Water $\mathrm{pH}$ shown a positive correlation with temperature where $\mathrm{r}=0.790$ and negative correlation with $\mathrm{DO}$ and Transparency where $\mathrm{r}=-0.492$ and -0.670 , respectively. DO maintained negative correlation with $\mathrm{pH}$ and Temperature and significant positive correlation with Transparency. Transparency had significant negative correlation with Temperature and $\mathrm{pH}$ where $\mathrm{r}=-0.803$ and -0.670 and highly positive correlation with DO where $\mathrm{r}=0.843(\mathrm{p}<0.01)$ (Table 2). In general, $\mathrm{pH}$ mostly temperature dependent and vice-versa whereas

\begin{tabular}{|c|c|c|c|c|}
\hline $\begin{array}{c}\text { Sampling months } \\
\text { and stations }\end{array}$ & $\begin{array}{c}\text { Temperature } \\
\left.\mathbf{}^{\circ} \mathbf{C}\right)\end{array}$ & $\mathbf{p H}$ & $\mathbf{D O}(\mathbf{m g} / \mathbf{l})$ & $\begin{array}{c}\text { Transparency } \\
(\mathbf{c m})\end{array}$ \\
\hline Mar & $25.72 \pm 1.04^{\mathrm{c}}$ & $7.00 \pm 0.09^{\mathrm{b}}$ & $5.23 \pm 0.12^{\mathrm{c}}$ & $26.07 \pm 0.65^{\mathrm{d}}$ \\
\hline May & $26.68 \pm 0.44^{\mathrm{b}}$ & $6.83 \pm 0.18^{\mathrm{b}}$ & $5.02 \pm 0.17^{\mathrm{d}}$ & $26.83 \pm 1.17^{\mathrm{d}}$ \\
\hline Jul & $28.35 \pm 0.75^{\mathrm{a}}$ & $7.65 \pm 0.10^{\mathrm{a}}$ & $5.75 \pm 0.14^{\mathrm{b}}$ & $26.50 \pm 1.05^{\mathrm{d}}$ \\
\hline Sep & $25.55 \pm 0.49^{\mathrm{c}}$ & $6.98 \pm 0.15^{\mathrm{b}}$ & $5.62 \pm 0.19^{\mathrm{b}}$ & $32.67 \pm 1.03^{\mathrm{c}}$ \\
\hline Nov & $24.22 \pm 0.50^{\mathrm{d}}$ & $6.58 \pm 0.15^{\mathrm{c}}$ & $6.80 \pm 0.13^{\mathrm{a}}$ & $34.83 \pm 1.17^{\mathrm{b}}$ \\
\hline Feb & $21.95 \pm 0.65^{\mathrm{a}}$ & $6.50 \pm 0.13^{\mathrm{c}}$ & $6.95 \pm 0.14^{\mathrm{a}}$ & $37.17 \pm 1.17^{\mathrm{a}}$ \\
\hline St1 & $25.35 \pm 2.15^{\mathrm{a}}$ & $6.83 \pm 0.43^{\mathrm{a}}$ & $5.73 \pm 0.86^{\mathrm{a}}$ & $30.73 \pm 4.85^{\mathrm{a}}$ \\
\hline St2 & $25.35 \pm 2.69^{\mathrm{a}}$ & $7.02 \pm 0.41^{\mathrm{a}}$ & $5.90 \pm 0.79^{\mathrm{a}}$ & $30.83 \pm 4.96^{\mathrm{a}}$ \\
\hline St3 & $25.57 \pm 2.13^{\mathrm{a}}$ & $7.00 \pm 0.51^{\mathrm{a}}$ & $5.88 \pm 0.86^{\mathrm{a}}$ & $30.17 \pm 4.79^{\mathrm{a}}$ \\
\hline St4 & $25.65 \pm 2.10^{\mathrm{a}}$ & $6.95 \pm 0.37^{\mathrm{a}}$ & $5.87 \pm 0.83^{\mathrm{a}}$ & $30.50 \pm 5.47^{\mathrm{a}}$ \\
\hline St5 & $25.02 \pm 2.26^{\mathrm{a}}$ & $6.83 \pm 0.38^{\mathrm{a}}$ & $5.97 \pm 0.78^{\mathrm{a}}$ & $30.83 \pm 4.96^{\mathrm{a}}$ \\
\hline St6 & $25.53 \pm 2.25^{\mathrm{a}}$ & $6.92 \pm 0.44^{\mathrm{a}}$ & $6.02 \pm 0.74^{\mathrm{a}}$ & $31.00 \pm 4.56^{\mathrm{a}}$ \\
\hline
\end{tabular}

Table 1: Hydrological parameters of Sandha River recorded during March 2015 to February 2016.

\begin{tabular}{|c|c|c|c|c|}
\hline & Temperature & pH & DO & Transparency \\
\hline Temperature & 1 & $0.790^{* *}$ & $-0.690^{* *}$ & $-0.803^{* *}$ \\
\hline pH & $0.790^{* *}$ & 1 & $-0.492^{* *}$ & $-0.670^{* *}$ \\
\hline DO & $-0.690^{* *}$ & $-0.492^{* *}$ & 1 & $0.843^{* *}$ \\
\hline Transparency & $-0.803^{* *}$ & $-0.670^{* *}$ & $0.843^{* *}$ & 1 \\
\hline${ }^{* *}$ Correlation is significant at the 0.01 level (2-tailed)
\end{tabular}

Table 2: Pearson's correlation coefficient among selected water quality parameters of Sandha River.
DO partially or fully depends on Transparency and vice-versa i.e., one increased or decreased with related to others increasing or decreasing impact.

\section{Fish assemblage's structure}

A total of 55 fish species with 1968 individuals had been recorded from the catches of different fishing gears used in this experiment (Table 3). The most dominant species both from months and stations found in the Sandha River was Corica soborna with 177 individuals (9\%) followed by Puntius ticto having 130 individuals (6.61\%) and less dominant species were Hypophthalmichthys molitrix and Dasyatis zugei which contributed single individuals $(0.05 \%)$ (Table 3 and Figure 2$)$. One alien species named Hypophthalmichthys molitrix was caught during the May 2015 which indicated that the river sometimes is the place of exotic species. Out of 55 species of finfish vulnerable, endangered and critically endangered species were 8,4 and 4 respectively recorded from Sandha River during the study period.

\section{Fish diversity indices}

Table 4 represents fish diversity indices of recorded fish species. Among the different fish diversity indices, $\mathrm{H}$ value was ranged from 3.011 to 3.575 for all species regardless used any months or stations. $\mathrm{H}$-index of diversity had a positive correlation with 1-D index and Evenness. Among the months and stations, the 1-D index was found maximum (0.964) in St2 and minimum (0.936) during March 2015. A significant negative correlation existed among 1-D and D index of diversity where the $\mathrm{D}$ value was ranged from 0.036 to 0.064 . Highest (0.752) evenness value of diversity was shown in March 2015 and lowest (0.616) during September 2015. Among the months, the peak value (8.471) of Margalef was calculated during July and minimum value (4.600) in March 2015.

\section{Spatial and temporal relationship of fish assemblages}

The similarity level of fish species was checked based on cluster analysis using Bray-Curtis similarity matrix (Figure 3). Three major groups were identified through Bray-Curtis similarity matrix of which the first group consists of 25 fish species; the second group had 26 fish species and the third group with 4 species only.

\section{Correlation between water quality parameters and fish species abundance}

Correlation between water quality parameters and fish species abundance was determined both from months and stations using Pearson's correlation coefficient (Table 5). On the basis of months, an insignificant negative relation was found between Temperature and fish species abundance and $\mathrm{pH}$ and fish species abundance with $\mathrm{r}$ value -0.130 and -0.164 , respectively where positive relation was measured between DO and fish species abundance and Transparency and fish species abundance $(r=0.254$ and 0.446 , respectively). On the other hand, according to stations, Temperature, $\mathrm{pH}$, and $\mathrm{DO}$ had a positive relation with the abundance of fish species where $r=0.243,0.354$ and 0.136 , individually. But Transparency had significant negative relation with the occurrence of fish species $(r=-0.712)$.

\section{Reasons behind decline of fisheries resources of Sandha River}

Eight sources as observed by the fishermen community which was documented and ranked with the help of Garretts Ranking Technique (Table 6) in order to identify the reasons behind the decline of Sandha River fish species over the periods. Over-exploitation was reported as the most dynamic factor to declining fish species which ranked first (mean 
Citation: Ruma M, Hossain MM, Rahman MB, Nahar A, Siddik MAB (2017) Fish Community Structure of Sandha River: A Link Analysis towards Fisheries Management and Conservation. J Biodivers Endanger Species 5: 192. doi: 10.4172/2332-2543.1000192

Page 4 of 8

\begin{tabular}{|c|c|c|c|c|c|c|c|c|c|c|c|c|c|c|c|}
\hline Scientific Name & Species code & Mar & May & Jul & Sep & Nov & Feb & St1 & St2 & St3 & St4 & St5 & St6 & Species abundance & Composition (\%) \\
\hline Chanda nama* & C1 & 5 & 7 & 12 & 11 & 6 & 3 & 7 & 6 & 15 & 6 & 7 & 3 & 44 & 2.24 \\
\hline Pseudambassis ranga* & $\mathrm{C} 2$ & 0 & 5 & 7 & 6 & 5 & 4 & 2 & 3 & 10 & 4 & 5 & 3 & 27 & 1.37 \\
\hline Anabas testudineus & C3 & 3 & 5 & 6 & 7 & 0 & 7 & 2 & 5 & 18 & 1 & 2 & 0 & 28 & 1.42 \\
\hline Mystus vittatus & C4 & 9 & 8 & 5 & 11 & 17 & 12 & 14 & 11 & 9 & 8 & 7 & 13 & 62 & 3.15 \\
\hline Mystus cavasius* & C5 & 0 & 0 & 4 & 3 & 3 & 0 & 2 & 3 & 0 & 0 & 5 & 0 & 10 & 0.51 \\
\hline Mystus bleekeri & C6 & 0 & 8 & 8 & 7 & 11 & 5 & 7 & 4 & 11 & 12 & 2 & 3 & 39 & 1.98 \\
\hline Sperata aor* & $\mathrm{C} 7$ & 0 & 0 & 5 & 5 & 1 & 2 & 0 & 2 & 3 & 2 & 5 & 1 & 13 & 0.66 \\
\hline Rita rita ${ }^{* \star *}$ & $\mathrm{C} 8$ & 0 & 3 & 6 & 3 & 4 & 0 & 3 & 2 & 5 & 3 & 2 & 1 & 16 & 0.81 \\
\hline Nemachilus botia & C9 & 6 & 6 & 9 & 7 & 6 & 3 & 7 & 6 & 5 & 7 & 7 & 5 & 37 & 1.88 \\
\hline Xenentodon cancila & C10 & 5 & 0 & 4 & 1 & 2 & 4 & 2 & 4 & 3 & 0 & 3 & 4 & 16 & 0.81 \\
\hline Channa punctatus & C11 & 3 & 4 & 3 & 2 & 5 & 3 & 3 & 6 & 4 & 3 & 2 & 2 & 20 & 1.02 \\
\hline Channa striatus & $\mathrm{C} 12$ & 3 & 5 & 1 & 3 & 2 & 0 & 0 & 1 & 3 & 4 & 3 & 3 & 14 & 0.71 \\
\hline Tenualosa ilisha & C13 & 16 & 12 & 11 & 19 & 7 & 4 & 9 & 8 & 22 & 13 & 10 & 7 & 69 & 3.51 \\
\hline Gudusia chapra & C14 & 9 & 11 & 17 & 7 & 9 & 0 & 7 & 11 & 6 & 7 & 9 & 13 & 53 & 2.68 \\
\hline Corica soborna & C15 & 45 & 23 & 34 & 21 & 37 & 17 & 27 & 26 & 41 & 35 & 31 & 17 & 177 & 9 \\
\hline Cynoglossus cynoglossus & C16 & 8 & 4 & 2 & 1 & 3 & 0 & 3 & 2 & 0 & 4 & 5 & 4 & 18 & 0.91 \\
\hline Puntius sophore & C17 & 0 & 0 & 7 & 43 & 33 & 4 & 18 & 13 & 17 & 15 & 19 & 5 & 87 & 4.42 \\
\hline Puntius sarana*** & C18 & 0 & 2 & 1 & 3 & 2 & 0 & 1 & 3 & 0 & 0 & 3 & 1 & 8 & 0.41 \\
\hline Puntius ticto* & C19 & 23 & 12 & 29 & 32 & 23 & 11 & 21 & 23 & 37 & 9 & 14 & 26 & 130 & 6.61 \\
\hline Puntius chola & $\mathrm{C} 20$ & 0 & 4 & 5 & 2 & 4 & 0 & 0 & 3 & 5 & 2 & 3 & 2 & 15 & 0.76 \\
\hline Puntius terio & $\mathrm{C} 21$ & 0 & 2 & 3 & 6 & 0 & 0 & 2 & 0 & 0 & 0 & 5 & 4 & 11 & 0.56 \\
\hline Esomus danricus & $\mathrm{C} 22$ & 11 & 5 & 2 & 4 & 3 & 3 & 5 & 3 & 7 & 3 & 6 & 4 & 28 & 1.42 \\
\hline Chela cachius & $\mathrm{C} 23$ & 0 & 6 & 3 & 9 & 2 & 0 & 7 & 3 & 5 & 0 & 0 & 5 & 20 & 1.02 \\
\hline Salmostoma phulo & $\mathrm{C} 24$ & 12 & 3 & 5 & 12 & 3 & 0 & 5 & 7 & 3 & 10 & 3 & 7 & 35 & 1.78 \\
\hline Salmostoma bacaila & $\mathrm{C} 25$ & 21 & 13 & 4 & 37 & 19 & 12 & 17 & 13 & 23 & 11 & 19 & 23 & 106 & 5.38 \\
\hline Danio devario & $\mathrm{C} 26$ & 7 & 6 & 3 & 23 & 7 & 5 & 2 & 13 & 12 & 11 & 7 & 6 & 51 & 2.59 \\
\hline Labeo rohita & $\mathrm{C} 27$ & 0 & 3 & 1 & 0 & 2 & 0 & 1 & 2 & 2 & 0 & 0 & 1 & 6 & 0.30 \\
\hline Gibelion catla & $\mathrm{C} 28$ & 0 & 4 & 2 & 0 & 0 & 0 & 2 & 0 & 1 & 1 & 0 & 2 & 6 & 0.30 \\
\hline Rohtee cotio ${ }^{\star *}$ & $\mathrm{C} 29$ & 0 & 0 & 4 & 6 & 6 & 0 & 3 & 2 & 5 & 2 & 4 & 0 & 16 & 0.81 \\
\hline Amblypharyngodon mola & C30 & 0 & 5 & 13 & 38 & 5 & 22 & 3 & 7 & 33 & 7 & 4 & 29 & 83 & 4.22 \\
\hline Hypophthalmichthys molitrix & C31 & 0 & 1 & 0 & 0 & 0 & 0 & 0 & 0 & 1 & 0 & 0 & 0 & 1 & 0.05 \\
\hline Dasyatis zugei & C32 & 0 & 1 & 0 & 0 & 0 & 0 & 0 & 0 & 1 & 0 & 0 & 0 & 1 & 0.05 \\
\hline Eleotris fusca & C33 & 0 & 0 & 0 & 2 & 0 & 0 & 0 & 0 & 0 & 1 & 0 & 1 & 2 & 0.10 \\
\hline Setipinna phasa & C34 & 13 & 2 & 0 & 7 & 5 & 23 & 9 & 10 & 8 & 9 & 7 & 7 & 50 & 2.54 \\
\hline Thryssa purava & C35 & 11 & 3 & 6 & 17 & 16 & 12 & 17 & 7 & 13 & 4 & 12 & 12 & 65 & 3.30 \\
\hline Glossogobius giuris & C36 & 6 & 0 & 3 & 3 & 3 & 6 & 3 & 4 & 4 & 2 & 5 & 3 & 21 & 1.07 \\
\hline Pseudapocryptes elongates & C37 & 8 & 23 & 2 & 6 & 32 & 12 & 5 & 13 & 9 & 16 & 19 & 21 & 83 & 4.22 \\
\hline Taenioides cirratus & C38 & 26 & 26 & 7 & 9 & 21 & 17 & 17 & 11 & 9 & 19 & 27 & 23 & 106 & 5.38 \\
\hline Hyporamphuslim batus & C39 & 3 & 5 & 3 & 4 & 2 & 2 & 7 & 4 & 5 & 0 & 0 & 3 & 19 & 0.97 \\
\hline Heteropneustes fossilis & C40 & 3 & 3 & 0 & 2 & 2 & 0 & 0 & 3 & 4 & 0 & 0 & 3 & 10 & 0.51 \\
\hline Lates calcarifer & C41 & 4 & 2 & 3 & 2 & 3 & 2 & 3 & 2 & 7 & 3 & 1 & 0 & 16 & 0.81 \\
\hline Mastacembelus armatus ${ }^{* *}$ & $\mathrm{C} 42$ & 0 & 1 & 1 & 1 & 6 & 4 & 5 & 3 & 0 & 2 & 1 & 2 & 13 & 0.66 \\
\hline Macrognathus ara/* & $\mathrm{C} 43$ & 0 & 0 & 7 & 3 & 23 & 19 & 6 & 3 & 7 & 12 & 11 & 13 & 52 & 2.64 \\
\hline Nandus nandus* & C44 & 0 & 2 & 3 & 9 & 12 & 3 & 5 & 3 & 6 & 7 & 3 & 5 & 29 & 1.47 \\
\hline Chitala chitala** & $\mathrm{C} 45$ & 0 & 0 & 2 & 3 & 5 & 5 & 2 & 3 & 7 & 2 & 0 & 1 & 15 & 0.76 \\
\hline Colisa fasciata & C46 & 0 & 3 & 7 & 5 & 17 & 11 & 8 & 6 & 4 & 6 & 12 & 7 & 43 & 2.18 \\
\hline Pangasius pangasius ${ }^{\star \star *}$ & $\mathrm{C} 47$ & 0 & 1 & 4 & 1 & 3 & 0 & 1 & 2 & 3 & 2 & 1 & 0 & 9 & 0.46 \\
\hline Silonia silondia ${ }^{* *}$ & C48 & 0 & 0 & 3 & 3 & 14 & 9 & 7 & 3 & 5 & 8 & 3 & 3 & 29 & 1.47 \\
\hline Ailia coila & C49 & 0 & 9 & 7 & 8 & 6 & 3 & 2 & 5 & 7 & 2 & 6 & 11 & 33 & 1.68 \\
\hline Otolithoides pama & C50 & 12 & 7 & 7 & 14 & 12 & 21 & 11 & 13 & 22 & 7 & 14 & 6 & 73 & 3.71 \\
\hline Wallago attu & C51 & 5 & 3 & 2 & 2 & 3 & 1 & 3 & 5 & 2 & 3 & 2 & 1 & 16 & 0.81 \\
\hline Bagariusy arrellii ${ }^{* \star *}$ & C52 & 0 & 3 & 2 & 4 & 0 & 1 & 2 & 0 & 3 & 2 & 0 & 3 & 10 & 0.51 \\
\hline Nangra viridescens & C53 & 0 & 0 & 2 & 2 & 1 & 3 & 0 & 2 & 0 & 3 & 2 & 1 & 8 & 0.41 \\
\hline Monopterus cuchia* & C54 & 0 & 1 & 0 & 2 & 0 & 0 & 1 & 0 & 0 & 0 & 0 & 2 & 3 & 0.15 \\
\hline \multirow[t]{2}{*}{ Tetraodon fluviatilis } & C55 & 8 & 3 & 2 & 3 & 0 & 0 & 2 & 1 & 2 & 5 & 3 & 3 & 16 & 0.81 \\
\hline & & 285 & 265 & 289 & 441 & 413 & 275 & 298 & 295 & 434 & 295 & 321 & 325 & 1968 & 100 \\
\hline
\end{tabular}

As per IUCN of Bangladesh [26] $={ }^{*}$ Vulnerable; ${ }^{* *}$ Endangered and ${ }^{* * *}$ Critically Endangered

Table 3: Fish species abundance in different months and stations of Sandha River during March 2015 to February 2016. 
Citation: Ruma M, Hossain MM, Rahman MB, Nahar A, Siddik MAB (2017) Fish Community Structure of Sandha River: A Link Analysis towards Fisheries Management and Conservation. J Biodivers Endanger Species 5: 192. doi: 10.4172/2332-2543.1000192
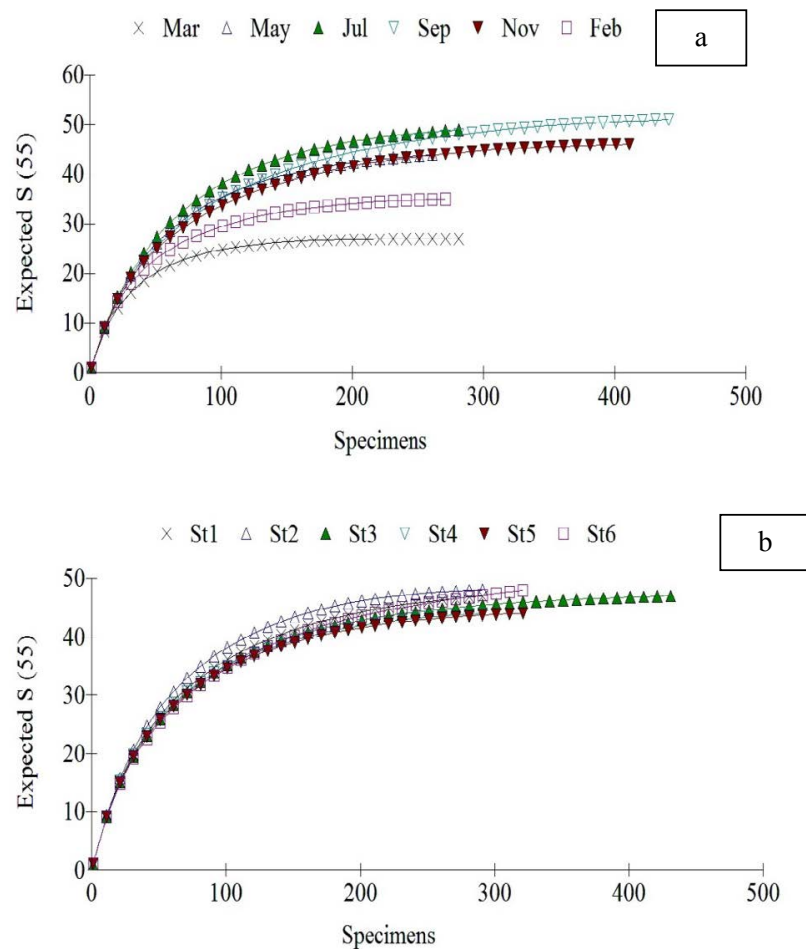

Figure 2: Rarefraction curve showing the abundance of fish species in the Sandha River according to months (a) and stations (b) score 52.594) among the reasons behind declining of fishery resources of Sandha River. Use of destructive fishing gears (mean score 50.848) was marked another dominating factor to reduce fish stock. In Sandha River, for fishing purpose different restricted fishing gears named set bag net, gill net (current jal), push net (moia jal) are frequently used to harvest a huge quantity of fish. Fishermen usually received low credit facilities (mean score 46.914) during fishing ban period which accountable for large-scale fishery caught. Non-point and point source pollution (4th rank) was informed as one of the major reasons for the decline in fisheries resources by the fisher's community. River bank erosion, climate change, fishing during ban period and natural disaster were got mean score 44.01 (V rank), 43.978 (VI rank), 40.65 (VII rank) and 39.878 (VIII rank), respectively. All of these reasons are changed Sandha River fish stock substantially.

\section{Discussion}

\section{Hydrological parameters}

Among the water quality parameters, Temperature is the most important one which affects the survivability, growth, metabolic activities of fish $[26,27]$. The recommended level of water temperature was $20^{\circ} \mathrm{C}$ to $30^{\circ} \mathrm{C}$ to maintain the aquatic ecosystem [28]. But in the present study, Temperature was found a negative correlation with fish species abundance (Table 5) which indicated that water temperature is at rising level. Temperature variation from month to month was noticeable while remains same condition in the same month of different stations of the river (Table 1). Solar radiation, ship breaking activities in Swarupkathi launch ghat and overall climate change was found as governing factors to change the water Temperature from

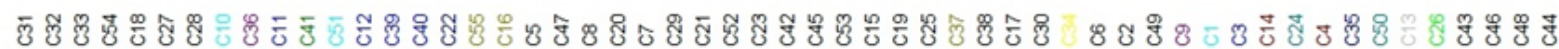

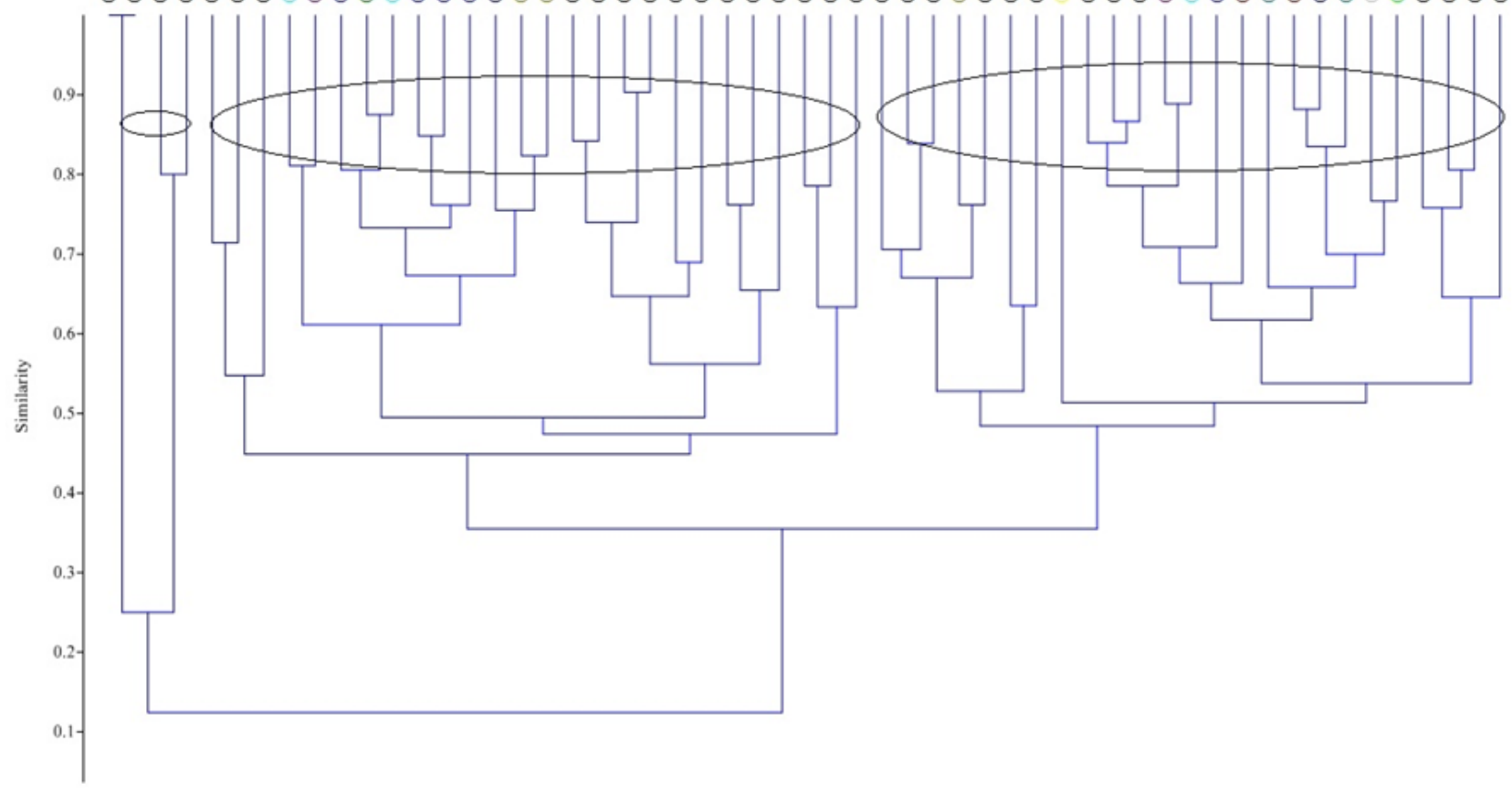

Figure 3: Spatial and temporal cluster of recorded fish assemblages based on Bray-Curtis similarity matrix. 
Citation: Ruma M, Hossain MM, Rahman MB, Nahar A, Siddik MAB (2017) Fish Community Structure of Sandha River: A Link Analysis towards Fisheries Management and Conservation. J Biodivers Endanger Species 5: 192. doi: 10.4172/2332-2543.1000192

Page 6 of 8

month to month in the present study area. The temperature had a positive correlation with water $\mathrm{pH}$ and vice-versa (Table 2). Among the water quality parameters, $\mathrm{pH}$ acts an indicator of the existence of aquatic life of any water body as most of the organisms could endure only narrow and critical $\mathrm{pH}$ range. The optimum range of $\mathrm{pH}$ for freshwater fish species is usually varied from 7.5 to 8.5 [29] where $\mathrm{pH}$ lower than 6.5 had a negative effect on fish growth [30]. From the study, an insignificant negative correlation was observed between water $\mathrm{pH}$ and fish species abundance (Table 5). Dissolved oxygen concentration is the most important water quality parameter which acts as the major factor triggering the species abundance, distribution and survivability in any water body $[31,32]$. DO was found negatively correlated with Temperature and $\mathrm{pH}$ while positive relation with Transparency (Table 3). DO concentrations lower than $5.0 \mathrm{mg} / \mathrm{L}$ would adversely affect the aquatic life [33]. But the present study recorded higher DO concentration (Table 1). This statement could also be verified in the case of fish species abundance which had a positive correlation with water DO concentration (Table 5). Transparency of water body mostly depends on the season, rainfall pattern and water current. Hossain et al. [32] reported that water transparency is a function of rainfall pattern. Hossain et al. [32] and Hanif et al. [12] found salinity concentrations zero (0) due to heavy freshwater discharge from surrounding land area and also related with annual rainfall pattern which supports the present study.

\section{Fish assemblage's structure}

Fish species of any water body shows varying degrees of dependency on human intervention, natural calamities and largely on environmental degradation. In the present study, a total of 1968 individuals under 55 fish species had been recorded from the catches of different fishing gears used in this experiment (Table 3 ) in which the most dominant species was Corica soborna followed by Puntius ticto both from months and stations of Sandha River. The result indicated that the river acts as the harbor of SIS. The outcomes were found similar in compare with the study of Hossain et al. [15] who identified that small fish species were dominant in Meghna River. Galib [34] identified total 67 species having 9837 individuals where Hanif et al. [35] listed 65323 individuals under 95 finfish species which were much higher than the present study. Dianne et al. [36] recorded a higher number of fish species than the present study which was 137 species from 42 families in the west coast of Western Australia. Lower fish species abundance could be described on the basis of several factors reported by fishermen which were ranked according to Garretts Ranking Technique (Table 6). Most of the fishermen used Sandha River as a sole source of income due to lack of sufficient job and credit facilities as a means of employment

\begin{tabular}{|c|c|c|c|c|c|c|c|}
\hline & Taxa_S & Individuals & H & Evenness & D & 1-D & Margalef \\
\hline Mar & 27 & 285 & 3.011 & 0.752 & 0.064 & 0.936 & 4.600 \\
\hline May & 44 & 265 & 3.437 & 0.707 & 0.043 & 0.957 & 7.706 \\
\hline Jul & 49 & 289 & 3.517 & 0.687 & 0.043 & 0.957 & 8.471 \\
\hline Sep & 51 & 441 & 3.448 & 0.616 & 0.045 & 0.955 & 8.211 \\
\hline Nov & 46 & 413 & 3.419 & 0.664 & 0.043 & 0.957 & 7.471 \\
\hline Feb & 35 & 275 & 3.247 & 0.735 & 0.048 & 0.952 & 6.053 \\
\hline S1 & 47 & 298 & 3.493 & 0.700 & 0.040 & 0.960 & 8.074 \\
\hline S2 & 48 & 295 & 3.575 & 0.743 & 0.036 & 0.964 & 8.264 \\
\hline S3 & 47 & 434 & 3.468 & 0.682 & 0.042 & 0.958 & 7.574 \\
\hline S4 & 44 & 295 & 3.453 & 0.718 & 0.042 & 0.958 & 7.561 \\
\hline S5 & 44 & 321 & 3.436 & 0.706 & 0.042 & 0.958 & 7.450 \\
\hline S6 & 48 & 325 & 3.429 & 0.643 & 0.044 & 0.956 & 8.126 \\
\hline
\end{tabular}

Table 4: Fish diversity indices of recorded fish species during March 2015 to February 2016.

\begin{tabular}{|c|c|c|}
\hline Correlation parameters & r value (months) & r value (stations) \\
\hline Temperature & -0.130 & 0.243 \\
\hline pH & -0.164 & 0.354 \\
\hline DO & 0.254 & 0.136 \\
\hline Transparency & 0.446 & -0.712 \\
\hline
\end{tabular}

Table 5: Pearson's correlation coefficient between fish species abundance and water quality parameters of Sandha River.

opportunity and food security. This was set off as a vital factor of excess fishing pressure by using different types of prohibited and restricted fishing gears in the river without maintaining government rules related to aquatic species. In addition, fishing activities during fishing ban period reduce spawned fish of Sandha River. Surplus catching of fish reduces the fish stock which causes the fish as threatened gradually. Non-point pollution and point source pollution especially municipal discharge, brick build industry along the coast of the river, agricultural runoff carrying harmful chemicals, oil discharge from water mechanical vehicles could alter the food webs of the river and normal life process of fish, destroying breeding, feeding and nursery grounds of precious fish species. River bank erosion is a common scenario faced by Sandha River fishermen. Due to river erosion, fisher's community lost their property as most of the fishermen live along the coast of the river. This is act as a promoting factor to harvest a huge amount of fish. Furthermore, environmental changes are the principal aspects which cause water level rising, warming the water and destroying cold water preferring fish species. All of the factors in combination reduce the fish species to a great extent from time to time. The findings were supported by $[4,36-39]$.

\section{Fish diversity indices}

Fish species diversity indices were calculated for both months and stations which were applied to understand as indicators of environmental and pollution stress faced by fish species. ShannonWiener index $(\mathrm{H})$ of diversity value (ranged from $0-5$ ) is commonly used to categorize the water quality status of any ecosystems. When $\mathrm{H}$ value of fish diversity is 5-4 indicating very good quality, 4-3 good quality, 3-2 moderate quality, 2-1 poor quality and very poor quality $<1$ [40]. In addition, $\mathrm{H}$ value $>3$ expresses clear water with a good diversity of aquatic species and value less than 3 specify polluted water [41]. In the present study, the calculated $\mathrm{H}$ value was found above 3 (Table 4) which suggested that the water conditions of Sandha River still transparent with a good quality ecosystem. In general, the result clear indicated that Shannon-Wiener index $(\mathrm{H})$ of diversity has a positive correlation with Evenness value, Simpson's index of diversity (1-D) and Margalef richness value of fish species diversity. The value of Evenness (E) usually ranged from 0 and $1[4,42]$ where the closer to 1 the more even the populations of fish that form the community. In the present findings, the Evenness value found almost closer to 1 (Table 4) which indicated the very few or no dominating species in the Sandha River. Similar result ranged for Evenness index also observed from the findings of other studies [4,32]. Simpson's dominance index (D) and Simpson's index of diversity (1-D) are negatively correlated which value ranged from 0 to 1 ( 0 , represents no dominance/complete diversity and 1 , represents complete dominance/no diversity) $[4,43]$. In the Sandha River, after polling all individuals the calculated value of $\mathrm{D}$ was shown that the river had very few dominated fish species thus with higher diversified fish community structure (Table 4). Other indices like Margalef richness has a positive correlation with food webs of an ecosystem i.e., higher richness value indicating longer food chain [41] Margalef in the study area was ranged from 4.6 to 8.471 which indicated the river had healthy to high-quality food chains. In general, diversity 
Citation: Ruma M, Hossain MM, Rahman MB, Nahar A, Siddik MAB (2017) Fish Community Structure of Sandha River: A Link Analysis towards Fisheries Management and Conservation. J Biodivers Endanger Species 5: 192. doi: 10.4172/2332-2543.1000192

Page 7 of 8

\begin{tabular}{|c|c|c|c|c|c|c|c|c|c|c|c|c|}
\hline \multirow{2}{*}{$\begin{array}{l}\text { Reasons behind decline of fisheries } \\
\text { resources of Sandha River }\end{array}$} & \multicolumn{8}{|c|}{ Rank given by respondents } & \multirow{2}{*}{$\begin{array}{l}\text { Total no. of } \\
\text { respondents }\end{array}$} & \multirow{2}{*}{$\begin{array}{l}\text { Total } \\
\text { score }\end{array}$} & \multirow{2}{*}{$\begin{array}{l}\text { Mean } \\
\text { score }\end{array}$} & \multirow{2}{*}{ Rank } \\
\hline & $1^{\text {st }}$ & $2^{\text {nd }}$ & $3^{\text {rd }}$ & $4^{\text {th }}$ & $5^{\text {th }}$ & $6^{\text {th }}$ & $7^{\text {th }}$ & $8^{\text {th }}$ & & & & \\
\hline Over exploitation & 87 & 69 & 65 & 56 & 63 & 53 & 59 & 48 & 500 & 26297 & 52.594 & 1 \\
\hline Use of destructive fishing gears & 82 & 65 & 55 & 50 & 65 & 58 & 63 & 62 & 500 & 25424 & 50.848 & II \\
\hline Inadequate credit facilities & 60 & 55 & 62 & 60 & 57 & 67 & 0 & 139 & 500 & 23457 & 46.914 & III \\
\hline Industrial pollution & 66 & 54 & 55 & 48 & 51 & 54 & 53 & 119 & 500 & 23308 & 46.616 & IV \\
\hline River bank erosion & 47 & 69 & 43 & 75 & 32 & 23 & 37 & 174 & 500 & 22005 & 44.010 & V \\
\hline Climate change & 49 & 48 & 53 & 52 & 53 & 49 & 50 & 146 & 500 & 21989 & 43.978 & VI \\
\hline Fishing during ban period & 73 & 29 & 36 & 62 & 0 & 0 & 98 & 202 & 500 & 20325 & 40.650 & VII \\
\hline Natural disaster & 27 & 43 & 31 & 37 & 48 & 78 & 83 & 153 & 500 & 19939 & 39.878 & VIII \\
\hline
\end{tabular}

Table 6: Perception of Sandha River fisheries regarding the reasons behind decline of fish species abundance.

indices value varied depending upon the number of species as well as a number of individuals in each fish species $[11,32,41]$.

\section{Spatial and temporal relation of fish diversity}

Similarity level between or among the species mainly used to know how much one species is similar to another one. For similarity test, cluster analysis techniques are commonly used to study the community association on the basis of distributional co-occurrence [44]. In this experiment, Bray-Curtis similarity matrix was used based on cluster analysis to find out the similarity level among the individual fish species. In the feedback, three majors groups were formed of which the first group observed as dominating characters where the second group had less dominating behavior and some of them season dependent and third group recognized as mostly season dependent and some of them were alien species. The findings of the present study were more or less similar to other studies [45-48].

In general, based on statistical analysis and result of fish species diversity indices, it would conclude that Sandha River still acts as a good environment for aquatic species. But day by day, the river is experienced with more sophisticated fishing technologies which responsible for large-scale fishery caught and environmental variables especially water Temperature are at rising level which changed food webs of the river and adversely affect the life process of fish. Thus in future, in a gathering of all adverse factors, the river will turn into species if the proper initiative does not set up to manage the aquatic resources of Sandha River.

\section{Conclusion}

Water quality data, fish species abundance, the value of fish diversity indices and correlation among and between hydrological parameters and fish species abundance would provide a conducive profile of Sandha River. In conclusion, the river is now facing excess fishing pressure which modifies the riverbed, destroying fish habitat and disturbing bottom preferring aquatic species. Information's about fish species assemblages and changes their number and compositions with the response of time and environmental variables (temperature, transparency, $\mathrm{pH}$ and $\mathrm{DO}$ ) could act a fundamental component to guide the aquatic resources from near extinction and sustainable use of these resources. However, an initiative like Community-based fisheries management is the most appropriate one to be adopted to manage the water resources. Other initiatives like provide alternative employment opportunities, use legal fishing gears, financial support during fish banning seasons etc. could be helpful to sustain the Sandha River fisheries resources.

\section{Acknowledgements}

The authors are grateful to all fishermen of Sandha River. The authors also felt thankful to the Department of Fisheries Management of Patuakhali Science and Technology University for laboratory facilities. The research was funded by Patuakhali Science and Technology University, Bangladesh.

\section{References}

1. Bell JD, Kronen M, Vunisea A, Nash WJ, Keeble G, et al. (2009) Planning the use of fish for food security in the Pacific. Marine Policy 33: 64-76.

2. Tacon AG, Metian M, Turchini GM, De Silva SS (2009) Responsible aquaculture and trophic level implications to global fish supply. Rev Fish Sci 18: 94-105.

3. FAO- Fisheries and Aquaculture Report (2012) Workshop on Fishery Stock Indicators and Stock Status, Tehran, Iran. Food and Agriculture Organization of the United Nations (FAO). Rome, Italy pp:46.

4. Rahman MB, Hoque MS, Hasan MM (2015) Selectivity of fishing gears and their effects on fisheries diversity of Rabnabad Channel of Patuakhali District in Bangladesh. Academic Research International 6: 184-196.

5. Craig JF, Halls AS, Barr JJ, Bean CW (2004) The Bangladesh floodplain fisheries. Fish Res 66: 271-286.

6. Chaklader MR, Nahar A, Siddik MAB, Sharker R (2014) Feeding habits and die composition of Asian Catfish Mystus vittatus (Bloch, 1794) in shallow water of an impacted coastal habitat. World J Fish Mar Sci 6: 551-556.

7. Chakraborty SC, Hossain MA, Hoq ME (1995) Traditional inland fishing methods in Bangladesh. J Asiatic Soc Bangladesh Sci 21: 19-27.

8. Brander KM (2007) Global fish production and climate change. Proceedings of the National Academy of Sciences 104: 19709-19714.

9. Ficke AD, Myrick CA, Hansen LJ (2007) Potential impacts of global climate change on freshwater fisheries. Rev Fish Biol Fish 17: 581-613.

10. Chaklader MR, Siddik MAB, Hanif MA, Nahar A, Mahmud S, et al. (2016) Morphometric and meristic variation of endangered pabda catfish, Ompok pabda (Hamilton-Buchanan, 1822) from southern coastal waters of Bangladesh. Pakistan J Zool 48: 233-240.

11. Ahsan ME, Wahab MA, Siddik MAB, Alam MA, Sharker MR, et al. (2013) Impacts of inclusion of column feeder rohu (Labeo rohita) at different stocking densities on growth, production and environment in freshwater prawn-finfish polyculture system. Int J Biol Res 1: 48-54.

12. Hanif MA, Siddik MAB, Chaklader MR, Mahmud S, Nahar A, et al. (2015) Biodiversity and Conservation of Threatened Freshwater Fishes in Sandha River, South West Bangladesh. World Appl Sci J 33: 1497-1510.

13. Talwar PK, Jhingran AG (1991) Inland fishes of India and adjacent countries, vol. 12. IBH publishing Co. Pvt., Ltd., New Delhi, pp: 1158.

14. Siddik MAB, Chaklader MR, Hanif MA, Islam MA, Fotedar R (2016) Lengthweight relationships of four fish species from a coastal artisanal fishery southern Bangladesh. J Appl Ichthyol 32: 1300-1302.

15. Rahman AKA (2005) Freshwater Fishes of Bangladesh, ( $2^{\text {nd }}$ Edn.) Dhaka, Bangladesh, pp: 394

16. Siddik MAB, Hanif MA, Chaklader MR, Nahar A, Mahmud S (2016) Fishery biology of gangetic whiting Sillaginopsis panijus (Hamilton, 1822) endemic to Ganges delta, Bangladesh. Egyptian J Aqua Res 41: 307-313.

17. Shannon CE (1949) Communication in the presence of noise. In: Proceedings of the Institute of Radio Engineers 37: 1021.

18. Shannon CE, Weaver W (1963) The Mathematical Theory of Communications. University of Illinois Press, Urbana, IL, pp: 125. 
Citation: Ruma M, Hossain MM, Rahman MB, Nahar A, Siddik MAB (2017) Fish Community Structure of Sandha River: A Link Analysis towards Fisheries Management and Conservation. J Biodivers Endanger Species 5: 192. doi: 10.4172/2332-2543.1000192

19. Harper DAT (Ed.) (1999) Numerical Palaeobiology. John Wiley \& Sons, New Jersey, United States.

20. Simpson EH (1949) Measurement of diversity. Nature 163: 688

21. Margalef R (1968) Perspectives in Ecological Theory. University of Chicago Press, Chicago, IL, pp: 111

22. Brower JE, Zar JH (1977) Field and Laboratory Methods for General Ecology. WMC Brown Co. Publication, Dubuque, lowa.

23. Hammer $\varnothing$, Harper DAT, Ryan PD (2001) PAST: Paleontological statistics software package for education and data analysis. Palaeontologia Electronica 4: 9

24. McAleece N, Gage JDG, Lambshead PJD, Paterson GLJ (1997) Bio Diversity Professional statistics analysis software.

25. Garret HE, Woodworth RS (1969) Statistics in Psychology and Education. Vakils, Feffer and Simons Pvt Ltd, Bombay, pp: 329.

26. IUCN, Bangladesh (2013) Red book of threatened fishes of Bangladesh, IUCNThe world conservation union. xii+ pp: 116.

27. Gillooly JF, Brown JH, West GB, Savage VM, Charnov EL (2001) Effects of size and temperature on metabolic rate. Science 293: 2248-2251.

28. Islam MA, Siddik MAB, Hanif MA, Chaklader MR, Nahar A, et al. (2017) Length-weight relationships of four small indigenous fish species from an inland artisanal fishery, Bangladesh. J Appl Ichthyol 33: 851-852.

29. Boyd CE (1990) Water Quality in Ponds for Aquaculture. Birmingham, Ala.: Auburn University Press.

30. Lloyd R (1992) Pollution and Freshwater Fish. West Byfleet: Fishing News Books.

31. Masese FO, Muchiri M, Raburu PO (2009) Macroinvertebrate assemblages as biological indicators of water quality in the Moiben River, Kenya. African $J$ Aqua Sci 34: 15-26.

32. Siddik M, Chaklader M, Hanif M, Islam M, Sharker M, et al. (2016) Stock Identification of Critically Endangered Olive Barb, Puntius sarana (Hamilton, 1822) with Emphasis on Management Implications. J Aqua Res Dev 7: 411.

33. Sinha SN, Biswas M (2011) Analysis of physico-chemical characteristics to study the water quality of a lake in Kalyani, West Bengal. Asian J Experi Biol Sci 2: 18-22.

34. Chaklader MR, Siddik MAB, Hanif MA, Nahar A (2016) Size structure of finescale razorbelly minnow, Salmostoma phulo (Cyprinidae) inhabiting a coastal river of Bangladesh. Iranian J Fish Sci 15: 1348-1361.
35. Hanif MA, Siddik MAB, Chaklader MR, Nahar A, Mahmud S (2015) Fish diversity in the southern coastal waters of Bangladesh: present status, threats and conservation perspectives. Croatian J Fish 73: 148-161.

36. Dianne WL, Euan SH, Gary AK, Kim N, Marti JA (2007) Protection from fishing alters: the species composition of fish assemblages in a temperate-tropical transition zone. Mar Biol 152: 1197-1206.

37. Rahman MB, Hoque MS, Rahman MM, Nahar A (2017) Exploration of fishing gear and fisheries diversity of Agunmukha River at Galachipa Upazila in Patuakhali District of Bangladesh. Iranian J FishSci 16: 108-126.

38. Penczak T, Agostinho AA, Okada EK (1994) Fish diversity and community structure in two small tributaries of the Paraná River, Paraná State, Brazil. Hydrobiologia 294: 243-251.

39. Rahman MB, Hoque MS, Mukit SS, Azam M, Mondal M (2016) Gears specific Catch Per Unit Effort (CPUE) with special reference to declining causes of ichthyofauna in the Kajal River of Southern Bangladesh. Int J Fish Aqua Stud 4: 382-387.

40. Mishra A, Chakraborty SK, Jaiswar AK, Sharma AP, et al. (2010) Plankton diversity in Dhaura and Baigul reservoirs of Uttarakhand. Indian J Fish 57: 19-27.

41. Acharjee ML, Barat S (2014) Seasonal dynamics of ichthyodiversity in a hill stream of the Darjeeling Himalaya, West Bengal, India. J Threat Taxa 6: 66356648.

42. Krebs CJ (1999) Ecological Methodology (2 ${ }^{\text {nd }}$ Edn.) Addison Wesley Longman

43. Berger WH, Parker FL (1970) Diversity of planktonic Foraminifera in deep sea sediments. Science 168: 1345-1347.

44. Struass RE (1982) Statistical significance of species clusters in association analysis. Ecology, 63: 634-639.

45. Callaway R, Alsvag J, De Boois I, Cotter J, Ford A, et al. (2002) Diversity and community structure of epibenthic invertebrates and fish in the North Sea. ICES J Mar Sci: Journal du Conseil 59: 1199-1214.

46. Vendel AL, Lopes SG, Santos C, Spach HL (2003) Fish assemblages in a tidal flat. Brazilian Arch Biol Technol 46: 233-242.

47. Hanif MA, Siddik MAB, Nahar A, Chaklader MR, Rumpa RJ, et al. (2016) The Current Status of Small Indigenous Fish Species (SIS) of River Gorai, a Distributary of the River Ganges, Bangladesh. J Biodivers Endanger Species 4: $1-8$.

48. Ahsan ME, Siddik MAB, Sharker MR, Alam MA, Nahar A, et al. (2014). Fish species availability in the fish landing centers of Patuakhali, Bangladesh. International Journal of Scientific \& Technology Research 3: 220-225. 